\section{THE CONSTRUCTION OF SPORTS PUBLIC SERVICE SYSTEM FOR THE ELDERLY FROM THE PERSPECTIVE OF HEALTHY AGING}

\author{
ESTRUCTURA DEL SISTEMA DE SERVICIOS PÚBLICOS PARA LOS DEPORTES DE EDAD EN EL CONTEXTO DEL \\ ENVEJECIMIENTOSALUDABLE

\section{CONSTRUÇÃO DE UM SISTEMA DE SERVIÇO PÚBLICO DE DESPORTOS PARA IDOSOS SOB A PERSPECTIVA DO ENVELHECIMENTOSAUDÁVEL}

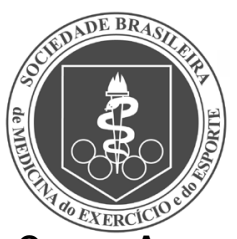

Original Article

ARTIGO ORIGINAL

Artículo Original

\begin{abstract}
Jie Sun ${ }^{1}$ (ID
(Public Health)

$\mathrm{Ke} \mathrm{Hu} u^{2}$ (DD

(Basic Medicine)

1. School of Physical Education, Hunan Institute of Science and Technology, Yueyang Hunan 414006, China.

2. School of Physical Education, Hunan City University, Yiyang Hunan 413000, China.
\end{abstract}

\section{Correspondence:}

Yueyang Hunan 414006, China. rmewit@163.com.

\begin{abstract}
With the gradual improvement of people's quality of life, the average life expectancy of our country has been extended. It is estimated that the total number of the elderly population in China will exceed 250 million by the end of 2020. Therefore, promoting healthy aging is a necessary measure to cope with the coming aging society in China, and physical exercise is an important method to keep the physical and mental health of the elderly. In order to promote the development of healthy aging in China, this study focused on the current level of public sports services for the elderly. This study uses the expert consultation method to test the rationality of the evaluation index, and uses the method of questionnaire survey to score each evaluation index, and uses the analytic hierarchy process (AHP) to calculate the weight of the index. Finally, the paper takes the public sports service of the elderly in a city as an example to verify. The results show that the level of sports public service for the elderly in this city is only 77,928 . Especially the two aspects of allocation of sports venues and the use of funds are the most unsatisfactory ones. It can be targeted to improve these two aspects, so as to improve the level of public sports services for the elderly. It is hoped that, through this study, we can provide some reference for improving the level of sports public service for the elderly from the perspective of healthy aging.
\end{abstract}

Keywords: Elderly people; public service; sports; analytic hierarchy process; expert consultation method.

\section{RESUMO}

Com a melhoria gradual da qualidade de vida das pessoas, a expectativa média de vida do nosso país foi ampliada. Estima-se que o número total de pessoas idosas na China excederá 250 milhões até o final de 2020. Por isso, promover um envelhecimento saudável é uma medida necessária para lidar com a futura população idosa na China, e o exercício físico é um método importante para manter a saúde física e mental dos idosos. A fim de promover o desenvolvimento de um envelhecimento saudável na China, este estudo centrou-se no nível atual de serviços desportivos públicos para os idosos. Este trabalho utiliza o método de consulta de especialistas para testar a racionalidade do índice de avaliação, e utiliza o método de levantamento por questionário para marcar cada índice de avaliação, e utiliza o processo hierárquico analítico (AHP) para calcular o peso do índice. Finalmente, a pesquisa toma como exemplo o serviço público de desportos dos idosos numa cidade. Os resultados mostram que o nível de serviço público desportivo para os idosos nesta cidade é apenas 77.928. Em especial, os aspectos da atribuição de espaços desportivos e a utilização de recursos financeiros são os mais insatisfatórios. Pode visar-se melhorar esses dois aspectos, de modo a melhorar o nível dos serviços desportivos públicos para os idosos. Espera-se que, através deste estudo, possamos oferecer uma referência para melhorar o nível de serviço público desportivo para os idosos sob a perspectiva do envelhecimento saudável.

Descritores: Idosos; serviço público; desporto; processo hierárquico analítico; método de consulta de especialistas.

\section{RESUMEN}

Con la mejora paulatina de la calidad de vida de las personas se ha ampliado la esperanza de vida media de nuestro país. Se estima que el número total de personas añosas en China superará los 250 millones a finales de 2020. Por lo tanto, promover un envejecimiento saludable es una medida necesaria para hacer frente al aumento de la edad de la sociedad en China. El ejercicio físico es un método importante para mantener la salud física y mental de las personas mayores. Con el fin de promover el desarrollo del envejecimiento saludable en China, este estudio se centró en el nivel actual de los servicios deportivos públicos para las personas añosas. Este estudio utiliza la consulta de expertos para probar la racionalidad del índice de evaluación, la encuesta de cuestionario para calificar cada índice de evaluación, y el proceso de jerarquía analítica (PJA) para calcular el peso del índice. Finalmente, el trabajo toma como ejemplo a serverificado, el servicio público deportivo de la tercera edad en una ciudad determinada. Los resultados muestran que el nivel de servicio público deportivo para personas añosas en esa ciudad es de solo 77.928. Especialmente los aspectos de la asignación de instalaciones deportivas y del uso 
de fondos son los más insatisfactorios. Se debe apuntar a mejorar estos dos aspectos, a fin de conseguir un mejor nivel de servicios deportivos públicos para las personas añosas. Esperamos que, a través de este estudio, podamos proporcionar una referencia para mejorar el nivel de servicio público deportivo para las personas añosas desde la perspectiva del envejecimiento saludable.

Descriptores: Personas de edad; servicios públicos; deportes; análisis de niveles; asesoramiento de expertos.

\section{INTRODUCTION}

With the continuous improvement of economic level, people's quality of life has been gradually improved, and the proportion of the elderly in the total population of the country is rising, and China is facing the situation of social aging. ' In response to the problem of aging population, comrade $X_{i}$ Jinping pointed out in the nineteen major reports of the party that we should adopt a positive attitude to cope with the aging of the population. Healthy aging is a method proposed by who in 1990 to deal with population aging. ${ }^{2}$ Its core theory is that the elderly adapt to the society well, mental health and physical health. According to the book "old age health Blue Book: China's elderly health research report", physical exercise is an effective way to improve the physical health of the elderly, and it also has a positive effect on the mental health of the elderly. ${ }^{3}$ At present, there are still some deficiencies in China's elderly sports public service, but the evaluation of the elderly sports public service is too subjective and fuzzy, there are no certain indicators and more accurate results, so it is difficult to evaluate the current level of sports public service for the elderly in China. ${ }^{4}$ Hope that through this study, can provide a certain reference for the construction of sports public service for the elderly in China. ${ }^{5}$

Through the research and analysis of domestic and foreign scholars, it can be seen that AHP has been used in various fields, and the effect is mostly good. This study not only uses the analytic hierarchy process, but also revises the research index through expert analysis method. It is hoped that this study can provide some reference for the further development of sports public service for the elderly in the perspective of healthy aging in China.

\section{The analytic hierarchy process (AHP) is used to evaluate the public service for the aged in a city}

In order to ensure the scientificity and scientificalness of the study, five experts in related fields were consulted by e-mail, telephone and door-to-door visit. The following Table 1 is the weight table of the first level index obtained by this study combined with expert guidance and AHP.

The above table is the weight table of the first level evaluation index in this study and the test results of its consistency. $C R=0.0328<0.1$ shows the rationality of the selected indicators. The following Table 2 shows the weight values of secondary indicators and their consistency inspection.

The above table is the weight table of the secondary evaluation index in this study and the test results of its consistency. It can be seen from the table that the consistency index value is less than 0.1 , so the

Table 1. The weight of the first-level evaluation index is the consistency test.

\begin{tabular}{c|c|c|c|c|c}
\hline First-level indicators & A & B & C & D & E \\
\hline$M_{i}$ & 12 & $3 / 4$ & 24 & $1 / 36$ & $1 / 6$ \\
\hline $\bar{W}_{i}$ & 1.423 & 0.871 & 2.225 & 0.487 & 0.501 \\
\hline$W^{\top}$ & 0.213 & 0.147 & 0.298 & 0.226 & 0.116 \\
\hline$A^{*} W^{\top}$ & 1.412 & 0.793 & 1.201 & 0.428 & 0.665 \\
\hline$\lambda_{\max }$ & \multicolumn{5}{c}{5.147} \\
\hline$C l$ & 0.329 \\
\hline$R I$ & 1.12 \\
\hline$C R$ & 0.0328 \\
\hline Eligibility & \multicolumn{5}{|c}{ YES }
\end{tabular}

selection of secondary index is also reasonable. The following Table 3 shows the three-level indicators of this study (lacono et al 2015).

The above table is the verification table of the weight of the three-level indicators in this study and the rationality of the index selection. It can be seen from the above table that the maximum consistency index value of the three-level indicators is 0.064 , which is less than the specified value of 0.1. Therefore, it can be considered that the selection of three-level indicators in this study is reasonable. Therefore, these indicators can be directly used to study the elderly sports public service system from the perspective of healthy aging. The data collection place of this study is the Sports Square in a city of China. Through the verified evaluation indicators, the elderly people who exercise in the square are investigated

Table 2. The weight of the secondary evaluation index is the consistency test.

\begin{tabular}{|c|c|c|c|c|c|c|c|c|c|}
\hline $\begin{array}{l}\text { Secondary } \\
\text { indicators }\end{array}$ & $M_{i}$ & $\bar{W}_{i}$ & $W^{T}$ & $A^{*} W^{T}$ & $\lambda_{\max }$ & $\mathrm{Cl}$ & $\mathbf{R I}$ & CR & Eligibility \\
\hline $\mathrm{A} 1$ & $2 / 3$ & 1.037 & 0.412 & 1.012 & \multirow{2}{*}{2.115} & \multirow{2}{*}{0.115} & \multirow{2}{*}{0} & \multirow{2}{*}{ / } & \multirow{2}{*}{ Yes } \\
\hline $\mathrm{A} 2$ & $3 / 2$ & 1.337 & 0.588 & 0.958 & & & & & \\
\hline B1 & 2 & 2.106 & 0.583 & 0.887 & \multirow{2}{*}{2.136} & \multirow{2}{*}{0.360} & \multirow{2}{*}{0} & \multirow{2}{*}{ / } & \multirow{2}{*}{ Yes } \\
\hline B2 & $1 / 2$ & 0.855 & 0.417 & 1.364 & & & & & \\
\hline $\mathrm{C} 1$ & 3 & 2.436 & 0.324 & 1.212 & \multirow{3}{*}{3.016} & \multirow{3}{*}{0.008} & \multirow{3}{*}{0.58} & \multirow{3}{*}{0.014} & \multirow{3}{*}{ Yes } \\
\hline $\mathrm{C} 2$ & $1 / 4$ & 0.601 & 0.247 & 0.741 & & & & & \\
\hline C3 & $4 / 3$ & 1.124 & 0.429 & 0.885 & & & & & \\
\hline D1 & 2 & 1.527 & 0.377 & 1.369 & \multirow{2}{*}{2.104} & \multirow{2}{*}{0.104} & \multirow{2}{*}{0} & \multirow{2}{*}{ / } & \multirow{2}{*}{ Yes } \\
\hline D2 & $1 / 2$ & 0.854 & 0.623 & 1.027 & & & & & \\
\hline E1 & 4 & 2.667 & 0.637 & 0.694 & \multirow{2}{*}{2.123} & \multirow{2}{*}{0.123} & \multirow{2}{*}{0} & \multirow{2}{*}{ / } & \multirow{2}{*}{ Yes } \\
\hline E2 & $1 / 4$ & 0.617 & 0.363 & 1.121 & & & & & \\
\hline
\end{tabular}

Table 3. Three-level evaluation index weight is consistency test.

\begin{tabular}{|c|c|c|c|c|c|c|c|c|c|}
\hline $\begin{array}{l}\text { Third-level } \\
\text { indicators }\end{array}$ & $M_{i}$ & $\bar{W}_{i}$ & $W^{\top}$ & $A^{*} W^{\top}$ & $\lambda_{\max }$ & $\mathrm{Cl}$ & RI & CR & Eligibility \\
\hline $\mathrm{A} 11$ & $1 / 2$ & 0.842 & 0.416 & 0.986 & \multirow{2}{*}{2.012} & \multirow{2}{*}{0.012} & \multirow[t]{2}{*}{0} & \multirow{2}{*}{ / } & \multirow{2}{*}{ Yes } \\
\hline $\mathrm{A} 12$ & 2 & 1.417 & 0.584 & 1.384 & & & & & \\
\hline A21 & 1 & 1.231 & 1 & 1.214 & 1.032 & 0.032 & 0 & I & Yes \\
\hline B11 & 2 & 1.365 & 0.396 & 1.267 & \multirow{3}{*}{3.015} & \multirow{3}{*}{0.008} & \multirow{3}{*}{0.58} & \multirow{3}{*}{0.013} & \multirow{3}{*}{ Yes } \\
\hline $\mathrm{B} 12$ & $1 / 3$ & 0.742 & 0.321 & 1.156 & & & & & \\
\hline B13 & $3 / 2$ & 1.003 & 0.283 & 0.906 & & & & & \\
\hline B21 & 2 & 1.327 & 0.301 & 0.993 & \multirow{3}{*}{3.024} & \multirow{3}{*}{0.012} & \multirow{3}{*}{0.58} & \multirow{3}{*}{0.021} & \multirow{3}{*}{ Yes } \\
\hline B22 & $1 / 2$ & 0.681 & 0.247 & 0.815 & & & & & \\
\hline B23 & 1 & 1.004 & 0.425 & 1.402 & & & & & \\
\hline $\mathrm{C} 11$ & 4 & 2.361 & 0.661 & 1.521 & \multirow{2}{*}{2.104} & \multirow{2}{*}{0.104} & \multirow{2}{*}{0} & \multirow{2}{*}{ / } & \multirow{2}{*}{ Yes } \\
\hline $\mathrm{C} 12$ & $1 / 4$ & 0.479 & 0.339 & 0.780 & & & & & \\
\hline $\mathrm{C} 21$ & 3 & 1.658 & 0.417 & 0.917 & \multirow{2}{*}{2.097} & \multirow{2}{*}{0.097} & \multirow{2}{*}{0} & \multirow{2}{*}{ / } & \multirow{2}{*}{ Yes } \\
\hline $\mathrm{C} 22$ & $1 / 3$ & 0.745 & 0.583 & 1.283 & & & & & \\
\hline C31 & 1 & 1.024 & 1 & 1.231 & 1.022 & 0.022 & 0 & 1 & Yes \\
\hline D11 & 5 & 2.553 & 0.287 & 0.947 & \multirow{3}{*}{3.074} & \multirow{3}{*}{0.037} & \multirow{3}{*}{0.58} & \multirow{3}{*}{0.064} & \multirow{3}{*}{ Yes } \\
\hline D12 & $1 / 7$ & 0.524 & 0.336 & 1.109 & & & & & \\
\hline D13 & $7 / 5$ & 0.995 & 0.377 & 1.244 & & & & & \\
\hline D21 & 6 & 2.669 & 0.498 & 1.145 & \multirow{2}{*}{2.101} & \multirow{2}{*}{0.101} & \multirow{2}{*}{0} & 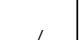 & Yoc \\
\hline D22 & $1 / 6$ & 0.631 & 0.502 & 1.155 & & & & 1 & res \\
\hline E11 & 1 & 1.143 & 1 & 1.203 & 1.024 & 0.024 & 0 & / & Yes \\
\hline E21 & $3 / 2$ & 1.389 & 0.441 & 0.970 & 2027 & 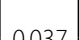 & 0 & 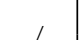 & \\
\hline E22 & $2 / 3$ & 0.875 & 0.559 & 1.230 & 2.031 & 0.031 & 0 & & res \\
\hline
\end{tabular}


by questionnaire survey, and the three-level indicators are evaluated by scoring in the survey report, and the total score is 100 . In the process of this study, 500 questionnaires were made according to the above evaluation indexes, and 365 questionnaires were collected after they were sent out. Moreover, there were some problems, such as incomplete data, damaged questionnaires, dirty data in the questionnaires. After simple pretreatment, a total of 315 questionnaires were sorted out. The average number in the questionnaire was taken as the result of each evaluation index. After sorting out, the results are shown in the Table 4 (Li Yanjiang et al 2017).

The above table shows the survey results of this study. Through the score of each value and the weight of each index, the comprehensive score of sports public service construction for the elderly in the city can be calculated as 77.928, which indicates that although the score of the elderly sports public service under the perspective of healthy aging in this City has passed, the score is not high, which indicates that the elderly sports public service in this city is not high The service level can also be improved. The weight of policy planning and implementation a in the table is $21.3 \%$, but its score is only 17.1 . The proportion of sports safety B was $14.7 \%$, and the score was 11.4. In terms of capital investment and use, C accounted for $29.8 \%$, with a score of 24.5 . The weight of sports field allocation D is $22.6 \%$, and its score is 15.5 . The weight of sports information dissemination and publicity e is $11.6 \%$, and the final score is only 9.5. The full score of this study is 100 points. The Figure 1 shows the comparison between the score of each first level index according to its weight and the actual score.

Table 4. Survey results.

\begin{tabular}{|c|c|c|c|c|c|c|}
\hline \multicolumn{2}{|c|}{ First-level indicators } & \multicolumn{2}{|c|}{ Secondary indicators } & \multicolumn{2}{|c|}{ Third-level indicators } & \multirow{2}{*}{$\begin{array}{c}\text { Score } \\
82 \\
\end{array}$} \\
\hline \multirow{3}{*}{ A } & \multirow{3}{*}{0.213} & \multirow{2}{*}{$\mathrm{A} 1$} & \multirow{2}{*}{0.412} & $\mathrm{~A} 11$ & 0416 & \\
\hline & & & & $\mathrm{A} 12$ & 0584 & 79 \\
\hline & & $\mathrm{A} 2$ & 0.588 & A21 & 1 & 80 \\
\hline \multirow{6}{*}{ B } & \multirow{6}{*}{0.147} & \multirow{3}{*}{ B1 } & \multirow{3}{*}{0.583} & B11 & 0.396 & 65 \\
\hline & & & & $\mathrm{B} 12$ & 0.321 & 92 \\
\hline & & & & B13 & 0.283 & 90 \\
\hline & & \multirow{3}{*}{ B2 } & \multirow{3}{*}{0.417} & B21 & 0301 & 88 \\
\hline & & & & B22 & 0247 & 74 \\
\hline & & & & B23 & 0425 & 68 \\
\hline \multirow{5}{*}{ C } & \multirow{5}{*}{0.298} & \multirow{2}{*}{ C1 } & \multirow{2}{*}{0.324} & $\mathrm{C} 11$ & 0661 & 74 \\
\hline & & & & $\mathrm{C} 12$ & 0339 & 86 \\
\hline & & \multirow{2}{*}{$\mathrm{C} 2$} & \multirow{2}{*}{0.247} & $\mathrm{C} 21$ & 0417 & 91 \\
\hline & & & & $\mathrm{C} 22$ & 0.583 & 77 \\
\hline & & $\mathrm{C} 3$ & 0.429 & C31 & 1 & 85 \\
\hline \multirow{5}{*}{ D } & \multirow{5}{*}{0.226} & \multirow{3}{*}{ D1 } & \multirow{3}{*}{0.377} & D11 & 0287 & 96 \\
\hline & & & & D12 & 0336 & 50 \\
\hline & & & & D13 & 0.377 & 77 \\
\hline & & \multirow{2}{*}{ D2 } & \multirow{2}{*}{0.623} & D21 & 0498 & 63 \\
\hline & & & & D22 & 0.502 & 68 \\
\hline \multirow{3}{*}{ E } & \multirow{3}{*}{0.116} & E1 & 0.637 & E11 & 1 & 81 \\
\hline & & \multirow{2}{*}{ E2 } & \multirow{2}{*}{0.363} & E21 & 0.441 & 79 \\
\hline & & & & E22 & 0559 & 85 \\
\hline
\end{tabular}

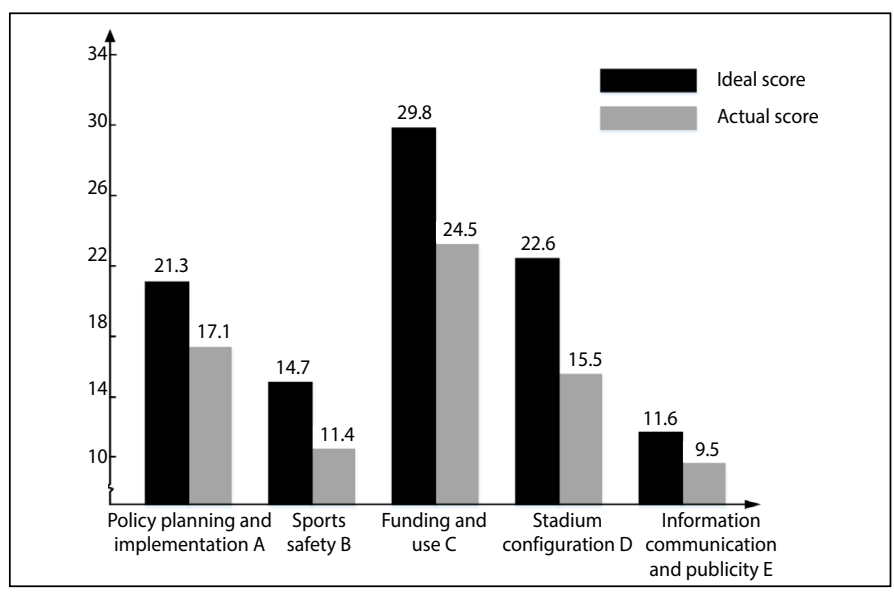

Figure 1. The ideal score and actual score of each indicator.

As can be seen from the above figure, the gap between the two indicators of sports venue allocation, capital investment and use and the ideal state is the largest. Therefore, we can improve the sports public service for the elderly from the perspective of healthy aging from the perspective of improving the allocation of sports venues, investment and use of funds.

\section{CONCLUSIONS}

The aging of the population is a problem that China has to face at present. The report of the 19th National Congress of the Communist Party of China pointed out that the health promotion action for the elderly is the top priority of the healthy China action. In order to improve the health level of the elderly and promote the development of healthy aging in China, this study combined with four principles to extract the current factors affecting the elderly sports public service, through expert consultation method, questionnaire method, analytic hierarchy process, and took the status quo of sports public service for the elderly in a City as the object, and verified by the way of examples. The results show that the scores of the five first level evaluation indexes extracted by this research have not reached their ideal values, and the allocation of sports venues and the use of funds are far from the ideal state. We hope that through this study, we can make a certain role in promoting the construction of sports public service for the elderly in our country. In the process of improving the public service system of sports for young people, we should aim at the existing problems and optimize them. However, there are still some deficiencies in this study. Due to the limitation of time and the number of researchers, the study only analyzes one city, and the universality of the study remains to be discussed.

\section{ACKNOWLEDGEMENT}

This paper is funded by National social science fund project: The Influence of Fertility Policy Adjustment on the Implementation of National Fitness Strategy and the Study of Policy Response(NO:17BTY046).

All authors declare no potential conflict of interest related to this article

AUTHORS' CONTRIBUTIONS: The author has completed the writing of the article or the critical review of its knowledge content. This paper can be used as the final draft of the manuscript. Each author has made an important personal contribution to this manuscript. Ke Hu, Jie Sun: writing and execution. Jie Sun: data analysis.

\section{REFERENCES}

1. Silva A. Universal health coverage and the health Sustainable Development Goal: achievements and challenges for Sri Lanka. WHO South-East Asia Journal of Public Health. 2016; 5(2):82-88.

2. Brusseau TA, Hannon J, Burns R. Effect of a Comprehensive School Physical Activity Program on Physical Activity and Health-Related Fitness in Children from Low-Income Families. Journal of Physical Activity \& Health. 2016; 13(8):888-894.

3. lacono AD, Eliakim A, Meckel Y. Improving fitness of elite handball players: small-sided games vs. high-intensity intermittent training. Journal of Strength \& Conditioning Research. 2015; 29(3):835-843.
4. Liu HC, Guo JQ, Xu QE. Correlation Analysis on Environmental Factors Influencing the Development of Urban and Rural Public Sports Equalization Service in South Jiangsu Province. Sports Science: English Version. 2017; 12(5):215-218.

5. Yanjiang L, Ciqin L. Research on the Change and Development of Public Sports Consumption Under the Background of Internet Plus Internet Background Research on the Change and Development of Mass Sports Consumption. Sports Culture Guide. 2019; 000(008): 84-89. 